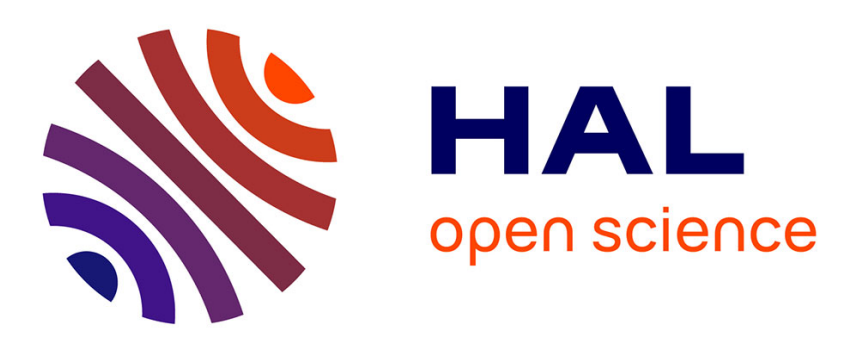

\title{
Citrulline modulates muscle protein metabolism in old malnourished rats
}

\author{
Sylwia Osowska, Thierry Duchemann, Stéphane Walrand, Alexandre Paillard, \\ Yves Y. Boirie, Luc Cynober, Christophe Moinard
}

\section{To cite this version:}

Sylwia Osowska, Thierry Duchemann, Stéphane Walrand, Alexandre Paillard, Yves Y. Boirie, et al.. Citrulline modulates muscle protein metabolism in old malnourished rats. AJP - Endocrinology and Metabolism, 2006, 291 (3), pp.E582-E586. 10.1152/ajpendo.00398.2005 . hal-02660228

\section{HAL Id: hal-02660228 https://hal.inrae.fr/hal-02660228}

Submitted on 30 May 2020

HAL is a multi-disciplinary open access archive for the deposit and dissemination of scientific research documents, whether they are published or not. The documents may come from teaching and research institutions in France or abroad, or from public or private research centers.
L'archive ouverte pluridisciplinaire HAL, est destinée au dépôt et à la diffusion de documents scientifiques de niveau recherche, publiés ou non, émanant des établissements d'enseignement et de recherche français ou étrangers, des laboratoires publics ou privés. 


\section{S. Osowska, T. Duchemann, S. Walrand, A. Paillard, Y. Boirie, L. Cynober and C. Moinard}

Am J Physiol Endocrinol Metab 291:582-586, 2006. First published Apr 11, 2006;

doi:10.1152/ajpendo.00398.2005

You might find this additional information useful...

This article cites 37 articles, 19 of which you can access free at:

http://ajpendo.physiology.org/cgi/content/full/291/3/E582\#BIBL

This article has been cited by 5 other HighWire hosted articles:

Glutamine: precursor or nitrogen donor for citrulline synthesis?

J. C. Marini, I. C. Didelija, L. Castillo and B. Lee

Am J Physiol Endocrinol Metab, July 1, 2010; 299 (1): E69-E79.

[Abstract] [Full Text] [PDF]

Voluntary wheel running is beneficial to the amino acid profile of lysine-deficient rats

K. Nagao, M. Bannai, S. Seki, N. Kawai, M. Mori and M. Takahashi

Am J Physiol Endocrinol Metab, June 1, 2010; 298 (6): E1170-E1178.

[Abstract] [Full Text] [PDF]

Splanchnic sequestration of amino acids in aged rats: in vivo and ex vivo experiments using a model of isolated perfused liver

M. Jourdan, L. Cynober, C. Moinard, M. C. Blanc, N. Neveux, J. P. De Bandt and C. Aussel Am J Physiol Regulatory Integrative Comp Physiol, March 1, 2008; 294 (3): R748-R755.

[Abstract] [Full Text] [PDF]

Maternal Supplementation With Citrulline Increases Renal Nitric Oxide in Young Spontaneously Hypertensive Rats and Has Long-Term Antihypertensive Effects M. P. Koeners, E. E. van Faassen, S. Wesseling, M. de Sain-van der Velden, H. A. Koomans, B. Braam and J. A. Joles

Hypertension, December 1, 2007; 50 (6): 1077-1084.

[Äbstract] [Full Text] [PDF]

\section{Manipulation of citrulline availability in humans}

C. Rouge, C. Des Robert, A. Robins, O. Le Bacquer, C. Volteau, M.-F. De La Cochetiere and D. Darmaun

Am J Physiol Gastrointest Liver Physiol, November 1, 2007; 293 (5): G1061-G1067.

[Abstract] [Full Text] [PDF]

Updated information and services including high-resolution figures, can be found at: http://ajpendo.physiology.org/cgi/content/full/291/3/E582

Additional material and information about AJP - Endocrinology and Metabolism can be found at: http://www.the-aps.org/publications/ajpendo

This information is current as of September 2, 2010 .

AJP - Endocrinology and Metabolism publishes results of original studies about endocrine and metabolic systems on any level of organization. It is published 12 times a year (monthly) by the American Physiological Society, 9650 Rockville Pike, Bethesda MD 20814-3991. Copyright @ 2006 by the American Physiological Society. ISSN: 0193-1849, ESSN: 1522-1555. Visit our website at http://www.the-aps.org/. 


\title{
Citrulline modulates muscle protein metabolism in old malnourished rats
}

\author{
S. Osowska, ${ }^{1}$ T. Duchemann, ${ }^{1}$ S. Walrand, ${ }^{2}$ A. Paillard, ${ }^{1}$ Y. Boirie, ${ }^{2}$ L. Cynober, ${ }^{1,3}$ and C. Moinard ${ }^{1}$ \\ ${ }^{1}$ Laboratoire de Biologie de la Nutrition, Faculté de Pharmacie, Université Paris 5; \\ ${ }^{2}$ UMPE, Laboratoire de la Nutrition Humaine, Clermont-Ferrand; and ${ }^{3}$ Laboratoire \\ Biochimie A, Hôtel-Dieu, Assistance Publique des Hopitaux de Paris, Paris, France
}

Submitted 24 August 2005; accepted in final form 30 March 2006

Osowska, S., T. Duchemann, S. Walrand, A. Paillard, Y. Boirie, L. Cynober, and C. Moinard. Citrulline modulates muscle protein metabolism in old malnourished rats. Am J Physiol Endocrinol Metab 291: E582-E586, 2006. First published April 11, 2006; doi:10.1152/ajpendo.00398.2005.-Protein energy malnutrition is common in the elderly, especially in hospitalized patients. The development of strategies designed to correct such malnutrition is essential. Our working hypothesis was that poor response to nutrition with advancing age might be related to splanchnic sequestration of amino acids, which implies that fewer amino acids reach the systemic circulation. Administration of citrulline, which is not taken up by the liver, can offer a means of increasing whole body nitrogen availability and, hence, improve nutritional status. Thirty old $(19 \mathrm{mo})$ rats were submitted to dietary restriction (50\% of food intake) for $12 \mathrm{wk}$. They were randomized into three groups: 10 rats ( $\mathrm{R}$ group) were killed and 20 others refed ( $90 \%$ of food intake) for 1 wk with a standard diet (NEAA group) or a citrulline-supplemented diet (Cit group). Before being killed, the rats were injected with $\left[{ }^{13} \mathrm{C}\right]$ valine, and the absolute protein synthesis rate (ASR) was measured in the tibialis using the flooding-dose method. When the rats were killed, the tibialis was removed for protein content analysis. Blood was sampled for amino acid and insulin analysis. The standard diet did not have any effect on protein synthesis or on the protein content in the muscle. Citrulline supplementation led to higher protein synthesis and protein content in muscle $(117 \pm 9,120 \pm 14$, and $163 \pm 4 \mathrm{mg} /$ organ for protein content in R, NEAA, and Cit groups, $P<0.05$ ). The ASR were $0.30 \pm 0.04$, $0.31 \pm 0.04$, and $0.56 \pm 0.10 \mathrm{mg} / \mathrm{h}$ in the three groups, respectively (R and NEAA vs. Cit, $P<0.05$ ). Insulinemia was significantly higher in the Cit group. For the first time, a realistic therapeutic approach is proposed to improve muscle protein content in muscle in frail state related to malnutrition in aging.

sarcopenia; malnutrition; protein synthesis

THE RISING NUMBER OF ELDERLY PEOPLE in Western countries has made successful aging a major health politic concern. Due to medico-economic implications, it makes sense to focus on the malnourished at-risk elderly population, especially as malnutrition is frequent in the elderly (34), from 30 to $60 \%$ in hospitalized persons. This lengthens hospital stay and increases morbidity and mortality (6). Also, the elderly exhibit a decreased ability to recover from a malnourished state $(17,18$, 33). It is clear that, at the molecular level, age-related malnutrition is accompanied by impaired protein metabolism $(9,13)$. In particular, it has been demonstrated $(5,36)$ that there is a significant increase in amino acid metabolism within the splanchnic area in the elderly compared with adults. This high splanchnic extraction of amino acids in the elderly leads to inadequate systemic plasma levels of amino acids in the post-

Address for reprint requests and other correspondence: C. Moinard, Laboratoire de Biologie de la Nutrition, Faculté de Pharmacie, Université Paris 5, 4 Ave. de l'Observatoire, 75270 Paris cedex 06, France (christophe.moinard@univ-paris5.fr). prandial period (26). Because hyperaminoacidemia (together with insulin) is one of the main stimulating factors for protein synthesis (31), the insufficient increase in postprandial plasma concentration of amino acids would result in blunted protein synthesis rates (3). Recently, we observed the same effect in elderly rats (19). On the basis of these data, strategies were developed to saturate this age-related abnormal splanchnic extraction (named splanchnic sequestration): high-protein diet (38), pulsed diet [80\% of protein in a single meal $(1,2)]$, or use of "fast proteins" (12). However, the practical application of these approaches is not necessarily easy in elderly malnourished patients. For this reason, we propose an alternative strategy. Our working hypothesis was that by using an amino acid that escapes splanchnic extraction, namely citrulline (43), it would be possible to deliver a more adequate amount of nitrogen [especially through citrulline conversion into arginine in the kidney (42)] to the peripheral tissues, including muscles, and thus to increase protein synthesis. Citrulline has a highly specific metabolism. The activity of the two enzymes that metabolize citrulline (argininosuccinate synthetase and argininosuccinate lyase) is very low in the intestine (37). It cannot be used in situ by enterocytes, and so citrulline is released as such into the circulation (41). Also, citrulline is not taken up by the liver (29). To test our working hypothesis, we chose a wellvalidated model of old malnourished rats in which an impaired response to renutrition has been proven (38).

\section{MATERIALS AND METHODS}

\section{Animals}

Thirty 19-mo-old, male Sprague-Dawley rats (Charles River, L'Arbresle, France) were used in the experiment. They were housed individually and kept at $20-23^{\circ} \mathrm{C}$ in alternate $12: 12$-h light-dark cycles. They had free access to water. During an acclimatization period, all rats were fed a standard diet ad libitum (UAR, Villemoisson-sur-Orge, France) for 2 wk. Daily spontaneous intakes were determined: these old rats consumed $34.4 \mathrm{~g} /$ day.

Animal care complied with the French regulations for the protection of animals used for experimental and other scientific purposes (D 2001-486) and with European Community regulations (Official Journal of the European Community, L538 12:18:1986).

\section{Experimental Procedures}

Dietary restriction. After the acclimatization period, the rats were given $50 \%$ of their spontaneous intakes recorded during the acclimatization period for $12 \mathrm{wk}$.

Refeeding. After the dietary restriction period, 10 rats were killed and 20 rats were refed for 1 wk. Food was limited to $90 \%$ of their spontaneous intake measured during acclimatization period (see

The costs of publication of this article were defrayed in part by the payment of page charges. The article must therefore be hereby marked "advertisement" in accordance with 18 U.S.C. Section 1734 solely to indicate this fact. 
Table 1. Protein content and ASR in the splanchnic area

\begin{tabular}{lccr}
\hline \hline & $\mathrm{R}$ & $\mathrm{NEAA}$ & \multicolumn{1}{c}{ Cit } \\
\hline Liver protein, g/organ & $2.75 \pm 0.14$ & $3.51 \pm 0.12 *$ & $3.35 \pm 0.15 \dagger$ \\
Liver ASR, mg/24 h & $0.997 \pm 0.096$ & $1.503 \pm 0.155 \dagger$ & $1.397 \pm 0.089$ \\
\hline
\end{tabular}

Values are means \pm SE. ASR, absolute protein synthesis rate; $R$, rats killed at the end of the restricted period; Cit, rats refed with a citrulline-supplemented diet; NEAA, rats refed with an NEAA-enriched diet. ANOVA + Duncan test: $* P<0.05$ vs. $\mathrm{R}$ and $\mathrm{Cit} ; \dagger P<0.05$ vs. $\mathrm{R}$.

above) to ensure that all rats ate all of their ration and, hence, received the same amounts of food. All the rats ate all their ration.

Experimental groups and plan. At the end of the acclimatization period, rats were randomized to the following groups. The "restricted" group ( $\mathrm{R}, n=10)$ underwent dietary restriction for $12 \mathrm{wk}$ and were killed at the end of the period of restriction. In the "citrulline" group (Cit, $n=10$ ), rats were refed for $1 \mathrm{wk}$, after $12 \mathrm{wk}$ of dietary restriction, with a citrulline supplement $\left(5 \mathrm{~g} \cdot \mathrm{kg}^{-1} \cdot \mathrm{day}^{-1}\right)$ and then killed. The dose of citrulline is the extrapolation of doses used in humans, taking into consideration that metabolic rate and nitrogen requirements are 10 times those of humans (10). In the "nonessential amino acid" group (NEAA, $n=10$ ), rats were refed, after $12 \mathrm{wk}$ of dietary restriction, for $1 \mathrm{wk}$ with a standard diet supplemented with nonessential amino acids (alanine, glycine, proline, histidine, aspartate, and serine in equimolar ratios) so that their nitrogen intake was equal to that of the Cit group.

After $1 \mathrm{wk}$, rats were killed. During the last 2 days of the experiment, rats were placed in individual metabolic cages, and urine was collected for determination of nitrogen balance and 3-methylhistidine excretion. Before being killed, the rats were injected with $\left[{ }^{13} \mathrm{C}\right]$ valine to determine the protein synthesis rate (see Protein mass in the tissues).

Tissue removal. Rats in the postabsorptive state were anesthetized with isoflurane and killed by beheading. Blood was sampled in heparinized tubes, which were rapidly centrifuged. The liver was immediately removed and weighed, and a sample was cut off, frozen in liquid nitrogen, and stored at $-80^{\circ} \mathrm{C}$ until analysis. For the jejunum and ileum, the intestine mucosa was washed with cold $\mathrm{NaCl}(0.9 \%)$, reverted and scraped, rapidly frozen in liquid nitrogen, and stored at $-80^{\circ} \mathrm{C}$ until analysis. A muscle of the hindlimbs (tibialis) was rapidly removed, weighed, frozen in liquid nitrogen, and stored at $-80^{\circ} \mathrm{C}$ until analysis. Tibialis was selected because this muscle is rich in type II fibers (24), and it is known (22) that muscles rich in type I fibers (i.e., soleus) are only marginally affected by advancing age.

\section{Parameters Studied and Analytic Methods}

Free amino acid concentrations in plasma and tissues. Frozen tissues (muscles, liver, and intestinal mucosa) were homogenized in ice-cold $10 \%$ trichloroacetic acid (TCA) containing $0.5 \mathrm{mmol} / \mathrm{l}$ EDTA and $125 \mu \mathrm{M}$ norvaline as a sample preparation internal standard. The acid-soluble fraction containing free amino acids was separated by centrifuging from precipitated proteins $\left(10 \mathrm{~min}, 2,500 \mathrm{~g}, 4^{\circ} \mathrm{C}\right)$. Tissue and plasma amino acid concentrations were determined by ion exchange chromatography with ninhydrin detection (JLC-500V; Jeol, Tokyo, Japan) (28). Results are expressed in micromoles per liter of plasma or micromoles per gram of tissue.

Our laboratory is registered in the European Quality Control Program (ERNDIM), ensuring the reliability of measurements for all the amino acids studied.

Urinary excretion. Myofibrillar protein degradation was evaluated by measuring excreted urinary 3-methylhistidine (3-MH) (20). 3-MH is released during myofibrillar protein breakdown without being either metabolized or reutilized for protein synthesis (44). In the rat, 3-MH is excreted chiefly in acetylated form. Samples were thus hydrolyzed with $\mathrm{HCl}(6 \mathrm{~mol} / \mathrm{l}$, vol/vol $)$ at $100^{\circ} \mathrm{C}$ for $12 \mathrm{~h}$, centrifuged $(30 \mathrm{~min}$,
$2,500 \mathrm{~g}, 4^{\circ} \mathrm{C}$ ), and filtered on $0.44-\mu \mathrm{m}$ filters before quantification by ion exchange chromatography with ninhydrin detection (L8500A; Hitachi, Tokyo, Japan) (21). Results are expressed in micromoles of 3-MH per millimole creatinine to take into account muscle mass in the evaluation of myofibrillar protein breakdown. (30).

Urinary creatinine excretion was measured as previously described

Nitrogen was quantified by chemiluminescence (29) using an Antek 9000 apparatus (Antek, Houston, TX), and nitrogen balance was calculated as the difference between nitrogen intake and nitrogen urinary output.

Plasma insulin and glucose. Plasma insulin concentrations were analyzed using a commercial RIA kit (INSIK-5; DiaSorin, Antony, France) with rat insulin as a standard (Linco, St. Louis, MO) (32).

Plasma glucose was measured by a hexokinase end point method at 340-380 nm (Olympus AU600, Rungis, France) (4).

Protein mass in the tissues. The frozen tissue was pulverized and homogenized in ice-cold 10\% TCA (1 ml TCA/100 mg tissue) using an Ultra-Turrax T25 tissue disrupter (Ika Labortechnik, Staufen, Germany). After delipidation with ethanol-ether (1:1, vol/vol), the precipitate was dissolved in $1 \mathrm{~N} \mathrm{NaOH}(4 \mathrm{ml} / 100 \mathrm{mg}$ tissue) for $12 \mathrm{~h}$ at $40^{\circ} \mathrm{C}$. The total protein content was then determined according to the method described by Fleury et al. (15) on a Genesys spectrophotometer (ThermoSpectronic, New York, NY).

Tissue protein synthesis rates were measured by the flooding-dose method (7). Just before being killed, each rat (in postabsortive state) was injected subcutaneously with a large dose of $\mathrm{L}-\left[{ }^{13} \mathrm{C}\right]$ valine $(99$ atom $\%, 300 \mu \mathrm{mol} / 100 \mathrm{~g}$; Cambridge Isotope Laboratories, Andover, MA) to flood the precursor pool of protein synthesis. Tracer incorporation was determined using the kinetics of incorporation of $\mathrm{L}-\left[{ }^{13} \mathrm{C}\right]$ valine from 20 to $50 \mathrm{~min}$, with rats from each group being killed at different times. A 200-mg piece of tissue was used. Measurement of $\mathrm{L}-\left[{ }^{13} \mathrm{C}\right]$ valine enrichment in hydrolyzed proteins was performed using GC-C-IRMS ( $\mu$ Gas System; Fisons Instruments, VG Isotech, Middlewich, UK). Amino acids in the tissue fluid were derivatized, and valine enrichments were used for precursor pool enrichment to calculate fractional synthesis rates (FSR) as previously described.

The FSR of proteins was calculated using the equation FSR = $\left(\mathrm{E}_{\mathrm{i}} \times 100\right) /\left(\mathrm{E}_{\text {prec }} \times t\right)$, where $\mathrm{E}_{\mathrm{i}}$ represents the enrichment as atom percent excess of ${ }^{13} \mathrm{C}$ derived from decarboxylation of valine from proteins at time $t$ (minus basal enrichment), $\mathrm{E}_{\text {prec }}$ is the mean enrichment in the precursor pool (tissue fluid $\left[{ }^{13} \mathrm{C}\right]$ valine), and $t$ is the incorporation time in hours.

Finally, the absolute synthesis rate (ASR) is calculated as ASR = $\mathrm{P} \times \mathrm{FSR}$, where $\mathrm{P}$ is the protein content. Data are expressed as milligrams per hour.

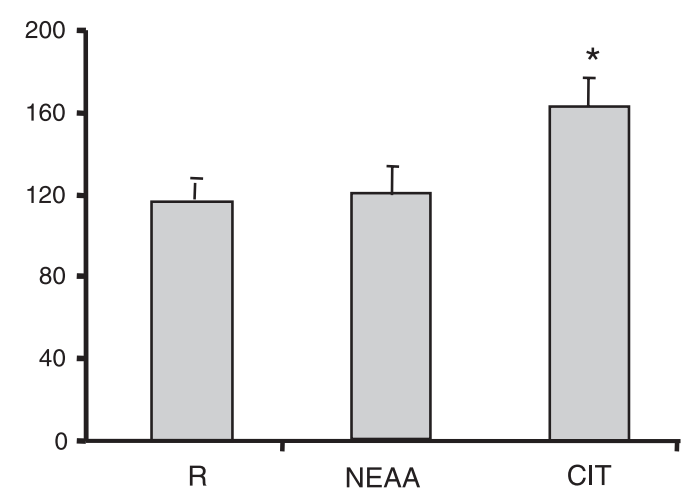

Fig. 1. Protein content in tibialis muscle (mg/organ). The 3 groups of rats were restricted for $12 \mathrm{wk}$. R, rats killed at the end of the restricted period; CIT, rats refed with a citrulline-supplemented diet; NEAA, rats refed with an NEAAenriched diet. ANOVA + Duncan test: $* P<0.05$ vs. R and NEAA. 


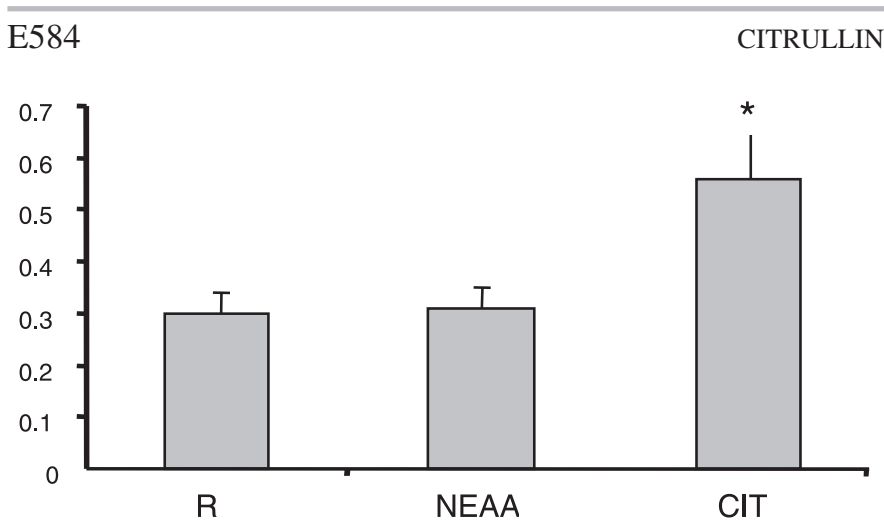

Fig. 2. Absolute protein synthesis rate in tibialis muscle (mg protein/h). ANOVA + Duncan test: $* P<0.05$ vs. $\mathrm{R}$ and NEAA.

\section{Statistical Analysis}

Data are expressed as means \pm SE. Comparisons between sets of data were made using one-way analysis of variance followed by the Duncan test. The PCSM software was used (Deltasoft, Grenoble, France). Differences at $P<0.05$ were considered significant.

\section{RESULTS}

\section{Protein Mass}

In the duodenum, the protein mass did not change between the groups (data not shown). In the liver, protein mass was significantly higher in the NEAA group compared with the R and $C$ it groups (NEAA vs. R and Cit, $P<0.05$; Table 1). It was also higher in the Cit group compared with the $\mathrm{R}$ group (Cit vs. NEAA, $P<0.05$ ). In the tibialis muscle, only supplementation with citrulline significantly increased protein mass in this muscle (Cit vs. R and NEAA, $P<0.05$; Fig. 1).

With respect to the 3-MH-to-creatinine ratio (3- $\mathrm{MH} /$ creatinine), myofibrillar proteolysis was unaffected by the different diets (data not shown).

\section{Protein Synthesis Rates}

Regarding the splanchnic area, in the duodenum there was no difference in protein synthesis rate between the groups.

In the liver, the protein synthesis rate was significantly increased only in the NEAA group compared with the $\mathrm{R}$ group (NEAA vs. R, $P<0.05$; Table 1 ).

In the tibialis muscle, only supplementation with citrulline led to a significantly higher ASR in this muscle compared with the other groups studied (Cit vs. NEAA and R, $P<0.05$; Fig. 2). Mean FSR was $27 \%$ higher in CIT-supplemented than in NEAA-supplemented rats, but the difference did not reach significance (Table 2).

\section{Nitrogen Balance}

Nitrogen balance in both refed groups (NEAA: 1,308 \pm 72; Cit: $1,035 \pm 94 \mathrm{mg} / 48 \mathrm{~h}$ ) was higher (NEAA and Cit vs.

Table 2. Weight and FSR of tibialis muscle

\begin{tabular}{lclc}
\hline \hline Muscles & \multicolumn{1}{c}{$\mathrm{R}$} & \multicolumn{1}{c}{ NEAA } & Cit \\
\hline Weight, mg & $0.74 \pm 0.10$ & $0.90 \pm 0.05^{*}$ & $0.85 \pm 0.12^{*}$ \\
FSR, $\% / \mathrm{h}$ & $0.26 \pm 0.02$ & $0.28 \pm 0.04$ & $0.34 \pm 0.05$ \\
\hline \multicolumn{2}{c}{ Values are means \pm SE. FSR, fractional synthesis rate. ANOVA + Duncan } \\
test: $* P<0.05$ vs. R FSR.
\end{tabular}

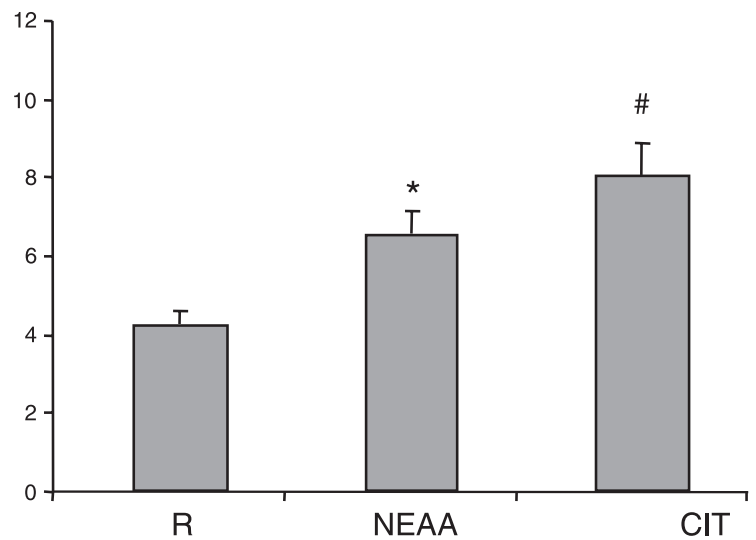

Fig. 3. Insulin concentration in the plasma (IU/l). ANOVA + Duncan test: $* P<0.05$ vs. $\mathrm{R} ; \# P<0.05$ vs. $\mathrm{R}$ and NEAA.

$\mathrm{R}, P<0.05)$ compared with the restricted group $(308 \pm 50$ $\mathrm{mg} / 48 \mathrm{~h}$ ).

\section{Plasma Insulin}

Insulin concentrations were higher in the NEAA group compared with the $\mathrm{R}$ group (NEAA vs. R, $P<0.05$; Fig. 3 ). Citrulline supplementation led to even higher insulin levels (Cit vs. $\mathrm{R}$ and NEAA, $P<0.05$ ) without change in glycemia (data not shown).

\section{Amino Acid Concentrations}

Among the 25 amino acids measured, concentrations of citrulline, ornithine, and arginine were the only ones that displayed significant variations according to the diet manipulations. They were higher in the plasma and the tibialis muscle in the Cit group after the renutrition period (Cit vs. R and NEAA, $P<0.05$; Table 3 ).

\section{DISCUSSION}

Protein-energy malnutrition is common in the elderly, especially in hospitalized patients. There is a close correlation between severity of protein-energy malnutrition and morbidity and mortality risk. However, the capacity of malnourished elderly persons to respond successfully to renutrition is lower than that of younger adults (17). The mechanism responsible for this response deficit (14) may include a higher splanchnic extraction of amino acids $(5,16)$ in older than in young adults, which implies that fewer amino acids reach the systemic

Table 3. Amino acid concentrations in plasma and tibialis muscle

\begin{tabular}{lccc}
\hline \hline & $\mathrm{R}$ & NEAA & Cit \\
\hline Plasma & & & \\
Citrulline, $\mu \mathrm{mol} / \mathrm{l}$ & $104 \pm 7$ & $155 \pm 20$ & $2394 \pm 279^{*}$ \\
Ornithine, $\mu \mathrm{mol} / \mathrm{l}$ & $41 \pm 3$ & $43 \pm 6$ & $223 \pm 27^{*}$ \\
Arginine, $\mu \mathrm{mol} / \mathrm{l}$ & $118 \pm 4$ & $99 \pm 7$ & $561 \pm 55^{*}$ \\
Muscle & & & \\
Citrulline, $\mathrm{nmol} / \mathrm{g}$ & $26 \pm 4$ & $50 \pm 11$ & $616 \pm 104^{*}$ \\
Ornithine, $\mathrm{nmol} / \mathrm{g}$ & $6 \pm 0$ & $3 \pm 0$ & $20 \pm 4^{*}$ \\
Arginine, $\mathrm{nmol} / \mathrm{g}$ & $66 \pm 3$ & $22 \pm 3$ & $203 \pm 35^{*}$ \\
\hline Values are means \pm SE. ANOVA + Duncan test: $* P<0.05$ vs. $\mathrm{R}$ and \\
NEAA.
\end{tabular}


circulation (26). Some nutritional manipulations are promising $(1,2,12,38)$ but are difficult to perform in practice. The choice of citrulline as a potential tool to increase muscle protein synthesis appears to be an elegant and very logical strategy. As a matter of fact, among amino acids citrulline has a unique metabolism: it is not used by the intestine, and it is not taken up by the liver (11). Hence, administering citrulline is a tool to deliver nitrogen (through endogenous metabolism into arginine) available for protein synthesis in the peripheral tissues, including the muscle.

The results obtained herein confirm our hypothesis. We have shown that standard nutrition led to increased protein mass and synthesis only in the liver and had no effect on the muscle. The lack of stimulation of muscle protein synthesis is in agreement with the only study, to our knowledge, performed on old, 10-day-starved rats in which refeeding with a standard diet showed no effect on the muscle protein synthesis rate (25).

Conversely, citrulline supplementation did not affect either protein mass or protein synthesis in the splanchnic area, which confirms that it bypasses this area. The hepatic citrulline pool is strictly compartmentalized in the mitochondria of hepatocytes and does not mix with circulating citrulline (11). Conversely the citrulline-enriched diet exerted a remarkably stimulating effect on the protein synthesis in the muscle, and as a consequence the protein mass of the studied muscle was also significantly increased. This result is very impressive, as there is so far no study available in the literature showing such a protein synthesis stimulation in the old malnourished rat. The fact that the citrulline-supplementd diet increased the muscle synthesis whereas the NEAA-enriched diet increased liver protein synthesis probably explains why nitrogen balance was not different between groups. Further experiments using tracers exploring more tissues are required to confirm this hypothesis.

An increase in protein content is a result of increased protein synthesis only, as the 3-MH/creatinine ratio, which reflects myofibrillar proteolysis, remained unchanged in the three studied groups.

This study did not aim to determine the precise mechanisms by which citrulline administration influences protein synthesis. However, several hypotheses can be advanced that deserve further study.

Citrulline may simply be the vehicle taking nitrogen to the muscle, directly or through conversion into arginine in the kidney, and a greater availability of the latter would explain why protein synthesis increases.

Citrulline can act directly (or via arginine production) on protein synthesis. To date, the transductional properties of this amino acid are not known. Many molecular targets may be involved, and it would be of major interest to evaluate the effect of citrulline (vs. arginine) on the phosphorylation of signaling proteins causing anabolism, such as the mammalian target of rapamycin, ribosomal protein S6-kinase-1, Akt, etc. In the context of these future studies, it would be of interest to test in parallel amino acids that have proved to modulate protein synthesis in the elderly, e.g., a mixture of essential amino acid (35) and leucine alone (16).

Citrulline can act indirectly by stimulating insulin secretion. It is noteworthy that insulin levels were significantly higher in citrulline-supplemented rats than in controls, even though insulinemia still remained lower than in the old healthy rats (8).
The increased levels of insulin could be a result of increased levels of arginine, which is well known to be a potent inducer of insulin secretion (23). However, this effect may also be related to citrulline per se; it was recently shown (27) that citrulline at a physiological concentration $(0.1 \mathrm{mM})$ increased insulin release from rat isolated islets.

In conclusion, citrulline supplementation in the old malnourished rats increases protein content of the muscle by stimulating protein synthesis. Whether this effect is transposable to humans and whether this strategy can improve the clinical outcome of elderly malnourished patients requires further study. Also, further work is needed to determine the mechanisms (direct or indirect) involved in citrulline action. Also, there is a splanchnic sequestration of amino acids in a number of pathological situations (including trauma, cancer, and type 2 diabetes). Although the underlying mechanisms here are certainly different from those encountered with advanced age, evaluating the effects of citrulline supplementation in these various situations is of interest because they are all characterized by impaired muscle protein synthesis.

\section{GRANTS}

S. Osowska was the recipient of a fellowship from Laboratoires Biocodex. This work was supported in part by a grant from Laboratoires Biocodex and in part by a grant from the French Ministry of Research (contrat quatriennal EA 2498).

\section{REFERENCES}

1. Arnal MA, Mosoni L, Boirie Y, Houlier ML, Morin L, Verdier E, Ritz P, Antoine JM, Prugnaud J, Beaufrère B, and Mirand PP. Protein pulse feeding improves protein retention in elderly women. Am J Clin Nutr 69: 1202-1208, 1999.

2. Arnal MA, Mosoni L, Dardevet D, Ribeyre MC, Bayle G, Prugnaud J, and Patureau MP. Pulse protein feeding pattern restores stimulation of muscle protein synthesis during the feeding period in old rats. J Nutr 132: 1002-1008, 2002.

3. Bell JA, Fujita S, Volpi E, Cadenas JG, and Rasmussen BB. Short-term insulin and nutritional energy provision do not stimulate muscle protein synthesis if blood amino acid availability decreases. Am J Physiol Endocrinol Metab 289: E999-E1006, 2005.

4. Blanc MC, Neveux N, Laromiguiere M, Berard MP, and Cynober L. Evaluation of a newly available biochemical analyzer: the Olympus AU 600. Clin Chem Lab Med 38: 465-475, 2000.

5. Boirie Y, Gachon $\mathbf{P}$, and Beaufrère B. Splanchnic and whole-body leucine kinetics in young and elderly men. Am J Clin Nutr 65: 489-495, 1997.

6. Bouillanne O, Morineau G, Dupont C, Coulombel I, Vincent JP, Nicolis I, Benazeth S, Cynober L, and Aussel C. Geriatric Nutritional Risk Index: a new index for evaluating at-risk elderly medical patients. Am J Clin Nutr 82: 777-783, 2005.

7. Breuille D, Arnal M, Rambourdin F, Bayle G, Levieux D, and Obled C. Sustained modifications of protein metabolism in various tissues in a rat model of long-lasting sepsis. Clin Sci (Lond) 94: 413-423, 1998.

8. Caldefie-Chezet F, Moinard C, Minet-Quinard R, Gachon F, Cynober L, and Vasson M. Dexamethasone treatment induces long-lasting hyperleptinemia and anorexia in old rats. Metabolism 50: 1054-1058, 2001.

9. Chambon-Savanovitch C, Felgines C, Farges MC, Pernet P, Cezard J, Raul F, Cynober L, and Vasson MP. Severe dietary restriction initiated in aged rats: evidence for poor adaptation in terms of protein metabolism and intestinal functions. Eur J Clin Invest 29: 504-511, 1999.

10. Colomb V, Leturque A, Guihot G, Loizeau M, Lavie S, Colomer S, Ricour C, and Girard J. Route of nutrient delivery affects insulin sensitivity and liver glucose transporter expression in rat. Am J Physiol Endocrinol Metab 269: E827-E833, 1995.

11. Curis E, Nicolis I, Moinard C, Osowska S, Zerrouk N, Benazeth S, and Cynober L. Almost all about citrulline in mammals. Amino Acids 29: 177-205, 2005. 
12. Dangin M, Boirie Y, Guillet $\mathbf{C}$, and Beaufrère B. Influence of the protein digestion rate on protein turnover in young and elderly subjects. $J$ Nutr 132: 3228S-3233S, 2002.

13. Felgines C, Savanovitch C, Farges MC, Cynober L, and Vasson MP. Protein metabolism in rats during long-term dietary restriction: influence of aging. J Parenter Enteral Nutr 23: 32-37, 1999.

14. Fereday A, Gibson NR, Cox M, Pacy PJ, and Millward DJ. Protein requirements and ageing: metabolic demand and efficiency of utilization. Br J Nutr 77: 685-702, 1997.

15. Fleury $\mathbf{P}$ and Aberham R. Recherche sur le dosage des protéines par la méthode photométrique du biuret selon la technique de Gornall. Ann Biol Clin 9: 453-466, 1951.

16. Fujita $\mathbf{S}$ and Volpi E. Amino acids and muscle loss with aging. J Nutr 136: 277S-280S, 2006.

17. Hebuterne X, Broussard JF, and Rampal P. Acute renutrition by cyclic enteral nutrition in elderly and younger patients. JAMA 273: 638-643, 1995.

18. Hebuterne X, Schneider S, Peroux J, and Rampal P. Effects of refeeding by cyclic enteral nutrition on body composition: comparative study of elderly and younger patients. Clin Nutr 16: 283-289, 1997.

19. Jourdan M, Deutz NE, Cynober L, and Aussel C. Splanchnic extraction of leucine is increased in elderly rats studied at the fed state (Abstract). Clin Nutr 23: 815, 2004.

20. Kuhl DA, Mouser JF, Methvin JT, Hak EB, Hak LJ, and Dickerson RN. Alterations in N-acetylation of 3-methylhistidine in endotoxemic parenterally fed rats. Nutrition 14: 678-682, 1998.

21. Le Boucher J, Charret C, Coudray-Lucas C, Giboudeau J, and Cynober L. Amino acid determination in biological fluids by automated ion-exchange chromatography: performance of Hitachi L-8500A. Clin Chem 43: 1421-1428, 1997.

22. Lexell $\mathbf{J}$ and Downham D. What is the effect of ageing on type 2 muscle fibres? J Neurol Sci 107: 250-251, 1992.

23. Malaisse WJ. Amino acid-mediated insulin secretion. In: Metabolic and Therapeutic Aspects of Amino Acids in Clinical Nutrition (2nd ed.), edited by Cynober L. Boca Raton, FL: CRC, 2004, p. 321-336.

24. Maltin CA, Delday MI, Baillie AGS, Grubb DA, and Garlick PJ. Fiber-type composition of nine rat muscles. I. Changes during the first year of life. Am J Physiol Endocrinol Metab 257: E823-E827, 1989.

25. Mosoni L, Malmezat T, Valluy MC, Houlier ML, Attaix D, and Mirand PP. Lower recovery of muscle protein lost during starvation in old rats despite a stimulation of protein synthesis. Am J Physiol Endocrinol Metab 277: E608-E616, 1999.

26. Mosoni L, Valluy MC, Serrurier B, Prugnaud J, Obled C, Guezennec CY, and Patureau Mirand P. Altered response of protein synthesis to nutritional state and endurance training in old rats. Am J Physiol Endocrinol Metab 268: E328-E335, 1995.

27. Nakata $\mathbf{M}$ and Yada T. Nitric oxide-mediated insulin secretion in response to citrulline in islet beta-cells. Pancreas 27: 209-213, 2003.
28. Neveux N, David P, and Cynober L. Measurement of amino acid concentration in biological fluids and tissues using ion-exchange chromatography. In: Metabolic and Therapeutic Aspects of Amino Acids in Clinical Nutrition (2nd ed.), edited by Cynober L. Boca Raton, FL: CRC, 2004, p. 17-28.

29. Osowska S, Moinard C, Neveux N, Loï C, and Cynober L. Citrulline increases arginine pools and restores nitrogen balance after massive intestinal resection. Gut 53: 1781-1786, 2004.

30. Osowska S, De Bandt JP, Chaib S, Neveux N, Berard MP, and Cynober L. Efficiency of a cysteine-taurine-threonine-serine supplemented parenteral nutrition in an experimental model of acute inflammation. Intensive Care Med 29: 1798-1801, 2003.

31. Pacy PJ, Price GM, Halliday D, Quevedo MR, and Millward DJ. Nitrogen homeostasis in man: the diurnal responses of protein synthesis and degradation and amino acid oxidation to diets with increasing protein intakes. Clin Sci (Lond) 86: 103-116, 1994.

32. Schneid C, Darquy S, Cynober L, Reach G, and De Bandt JP. Effects of ornithine $\alpha$-ketoglutarate on insulin secretion in rat pancreatic islets: implication of nitric oxide synthase and glutamine synthase pathways. $\mathrm{BrJ}$ Nutr 89: 249-257, 2003.

33. Seiler WO. Clinical pictures of malnutrition in ill elderly subjects. Nutrition 17: 496-498, 2001.

34. Sullivan DH, Walls RC, and Bopp MM. Protein-energy undernutrition and the risk of mortality within one year of hospital discharge: a follow-up study. J Am Geriatr Soc 43: 507-512, 1995.

35. Volpi E, Kobayashi H, Sheffield-Moore M, Mittendorfer B, and Wolfe RR. Essential amino acids are primarily responsible for the amino acid stimulation of muscle protein anabolism in healthy elderly adults. Am J Clin Nutr 78: 250-258, 2003.

36. Volpi E, Sheffield-Moore M, Rasmussen BB, and Wolfe RR. Basal muscle amino acid kinetics and protein synthesis in healthy young and older men. JAMA 286: 1206-1212, 2001.

37. Wakabayashi Y. The glutamate crossway. In: Metabolic and Therapeutic Aspects of Amino Acids in Clinical Nutrition, edited by Cynober L. Boca Raton, FL: CRC, 2004, p. 135-152.

38. Walrand S, Chambon-Savanovitch C, Felgines C, Chassagne J, Raul F, Normand B, Farges MC, Beaufrère B, Vasson MP, and Cynober L. Aging: a barrier to renutrition? Nutritional and immunologic evidence in rats. Am J Clin Nutr 72: 816-824, 2000.

41. Windmueller HG and Spaeth AE. Source and fate of circulating citrulline. Am J Physiol Endocrinol Metab 241: E473-E480, 1981.

42. Wu G and Morris SM Jr. Arginine in mammals. In: Metabolic and Therapeutic Aspects of Amino Acids in Clinical Nutrition (2nd ed.), edited by Cynober L. Boca Raton, FL: CRC, 2004, p. 153-167.

43. Wu G, Meininger CJ, Knabe DA, Bazer FW, and Rhoads JM. Arginine nutrition in development, health and disease. Curr Opin Clin Nutr Metab Care 3: 59-66, 2000.

44. Young VR and Munro HN. Ntau-methylhistidine (3-methylhistidine) and muscle protein turnover: an overview. Fed Proc 37: 2291-2300, 1978. 